ELORE (ISSN 1456-3010), vol. $12-1 / 2005$.

Julkaisija: Suomen Kansantietouden Tutkijain Seura ry.

Toimittaneet: Outi Fingerroos ja Kaarina Koski. Taitto: Jukka Talve.

[http://cc.joensuu.fi/ loristi/1_05/dav1_05.pdf]

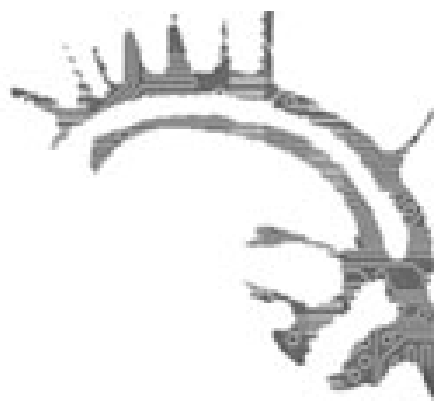

\title{
RITUAALI, IDENTITEETTI JA YLIRAJAISUUS
}

Joitakin ajatuksia paluumuuttajan hautajaisista

\section{Olga Davydova}

Tässä artikkelissa tarkastelen erään Venäjältä Suomeen muuttaneen miehen hautajaisia etnisen identiteetin tuottamisen näkökulmasta. Hänen hautajaisensa olivat ensimmäiset, joihin olen osallistunut Suomessa. Siksi hautajaiset ovat askarruttaneet mieltäni; artikkelissa lähteenä käyttämäni kuvaus perustuukin omaan kokemukseeni.

Olen viettänyt yli kolmanneksen elämästäni Itä-Suomessa, jonne muutin Petroskoista paluumuuttajan statuksella valmistuttuani sikäläisestä yliopistosta. Suomalaista syntyperää oleville silloisen Neuvostoliiton kansalaisille myönnettiin oikeus muuttaa Suomeen 1990-luvun alussa ja on arvioitu, että Suomeen muutti paluumuuttomenettelyn kautta yli 25000 henkeä. Paluumuuttajana olen ikään kuin "kolmiulotteinen". Ensinnäkin minulla on yhteinen tausta ja kokemusmaailma muiden Venäjältä Suomeen tulleiden paluumuuttajien kanssa. Toiseksi olen toiminut monta vuotta Petroskoissa järjestettävien maahanmuuttovalmennuskurssien koordinaattorina. Minulla siis on kokemusta myös viranomaisena toimimisesta. Lisäksi olen lähestynyt paluumuuton kontekstia tutkijan ominaisuudessa, sillä tarkastelin lisensiaattityössäni paluumuuttoa odottavien Venäjän suomalaisten suomalaisuuden muodostumista haastattelupuheessa (Davydova 2004).

Vuoden 2004 alussa järjestetyt hautajaiset olivat monella tavalla erikoiset. Pitkäaikainen paluumuuttajatuttavani Petroskoista kuoli yllättäen Joensuussa, jonne hänet myös haudattiin. Hautajaiset pidettiin luterilaisin menoin ja suomen kielellä, vaikka hautajaisväestä vain muutama ymmärsi suomea kunnolla. Suurin osa hautajaisvieraista oli Suomessa asuvia paluumuuttajia ja heidän perheenjäseniään tai Petroskoista tulleita vainajan sukulaisia, joiden äidinkieli oli venäjä. Ilmapiiri olikin jännittynyt ja oudoksuva. Esitän seuraavassa katkelmia muistiinpanoistani, jotka kirjoitin pian hautajaisten jälkeen. 


\section{Olga DaVydova}

[..] Tuntemani ibmiset, venäjänkieliset paluumunttajat, olivat pukeutuneet jotenkin arkisesti: monilla oli talvilenkekareita jalassa ja villapaitoja päällä. Näki, että he olivat pyrkineet laittamaan päälleen tummia vaatteita, mutta varsinaisesti jublavia surupukuja tai vaikekapa tummia miesten pukuja ei näkynyt. Muntama suomalainen erottui joukosta paremmilla vaatteillaan. Pappi piti pubeensa suomeksi, ja monelta sen sisältö jäi ymmärtämättä joko täysin tai osittain. Välillä pappi lukei erillisiltä lapuilta vaivalla ja epäselvästi mumisten muutaman sanan venäjäksi. Vieraiden joukossa joku yritti pitää munt tapabtumien tasalla kertomalla venäjäksi, mitä pappi pubui. [..] Surijat istuivat paikoillaan ja tuntuivat olevan aivan erillään siitä, mitä rituaalin vetäjät tekivät.

Lyhyen pubeen jälkeen pappi sanoi, että nyt saa laskea kukat. Kukaan ei liikk.kunut. Ajattelin, eivättë̈ he ymmärrä, pitääkö näyttää mallia ja kävelin kappelin ovelta arkulle, laskin kukekani niille tarkoitetulle telineelle. Sitten kuulin selkäni takaa äänen, joka selitti venäjäksi, että nyt viedään kukat nïn, että ensin sen tekevät läheisimmät sukulaiset ja sitten vasta ystävät ja tuttavat. Tajusin, että olin mokannut pahasti - olinhan minäkin ensimmäistä kertaa hautajaisissa Suomessa. [..]

Kun kaikeki olivat istuntuneet paikoilleen, kanttori aloitti sävelen, jonka tunnistin vainajan lempilauluksi. Jotkut naisista rupesivat itkemään ääneen. Soitto nimittäin soveltui tilaisuuteen erittä̈n byvin: Mibail Lermontovin peruskoulun kirjallisuuden opetussuunnitelmaan kuuluvasta Purje -runosta oli aikoinaan sävelletty surumielinen kaunis romanssi. "Meren usvasta hohtaa valkoisena yksinäinen purje. Mitä se hakee kaukaisesta maasta, minkä on byljännyt kotiseudulleen?" Kappaleen sisältö avautui kaikille hautajaisissa olleille venäläisille, muttei ilmeisesti suomalaisille osanottajille.

Hautajaiset jäivät askarruttamaan mieltäni, sillä jouduin pohtimaan kokemani hämmennyksen syitä. Onko hämmennys selitettävissä yhteisöllisistä lähtökohdista, esimerkiksi Suomen ja Venäjän hautaamistapojen erilaisuudella tai rituaalien takaa löytyvien kulttuuristen mallien, maailmankuvien ja ideologioiden avulla. Minkä hautaamistradition puoleen paluumuuttajan tai maahanmuuttajan on käännyttävä, jotta hän kokee löytäneensä "oikeanlaiset", "sopusointuiset" ja omia kulttuurisia odotuksia vastaavat hautajaisrituaalit. Vai onko kyseisiä hautajaisia sittenkin hedelmällisempää tarkastella uudenlaisesta kulttuurisesta prosessista käsin, jonka jäsentämisen ja selittämisen attribuutteiksi edelleenkin käytetään määreitä venäläinen ja suomalainen - vaikka prosessi ei enää palautuisikaan näihin määreisiin.

Tässä artikkelissa tarkastelen rituaalien ja identiteettien keskinäissuhdetta. Hautajaisten analyysissä ja taustoituksessa reflektoin omia kokemuksiani, koska tutkittavieni kanssa saman taustan omaavana ja kokemuksia jakavana pidän kokemuksiani tutkimusinstrumenttina. Artikkeli koostuu neljästä osasta. Ensin esittelen teoreettisen näkökulmani identiteetin ja rituaalin suhteesta. Sitten kuvaan entisestä Neuvostoliitosta Suomeen suuntautuvan paluumuuton ympärillä käytävää 
identiteettikeskustelua. Aiemman tutkimukseni pohjalta osoitan identiteettidiskurssin jännittyneisyyden ja politisoitumisen. Neuvostoliittolaista ja nykyvenäläistä hautajaisperinnettä käsittelevissä luvuissa esittelen kahden esimerkin avulla, millaista moniäänisyyttä venäläisiin hautaamistapoihin kätkeytyy. Artikkelin loppuosassa käsittelen joensuulaisen paluumuuttajan hautajaisia. Hautajaiset sijoittuvat transnationaaliin kultturiseen tilaan, joka on muodostunut Suomeen suuntautuvan paluumuuton vaikutuksesta. Tapahtumaa luonnehtii bybridisyys ja ristiriitainen identifioituminen.

\section{RituaAli ja IDENTITEETTI}

Lähden liikkeelle sellaisesta rituaalien tutkimuksen tavasta, joka suhteuttaa rituaalin sitä harjoittavaan yhteisöön. Rituaalianalyysin keinoin on mahdollista tulkita yksilöiden ja yhteisön kriisien ratkaisutapoja ja sosiaalisen järjestyksen eheyttämistä. Tällöin pohditaan rituaalisen toiminnan sosiaalisia funktioita ja merkityksiä. Lisäksi katsotaan, että rituaali välittää ja muokkaa sosiaalista kokemusta, määrittelee ja luo sitä: "Ihminen ei ole ainoastaan sosiaalinen, vaan myös rituaalinen eläin (Douglas 2001, 100).” Rituaalien tarkastelun kautta on analysoitu myös yhteisön uskomus- ja arvojärjestelmiä ja kulttuureja, jolloin keskiöön tulevat kuoleman ja kuolemattomuuden käsitykset (Huntington \& Metcalf 1979).

Tutkimassani maahanmuuttokontekstissa yksilön ja yhteisön välinen suhde ilmenee rituaaleissa kuitenkin vain näennäisesti, sillä kaanoninkin mukaan eteneviin rituaaleihin kehittyy sisäisiä ristiriitoja. Yksilön ja yhteisön välisen suhteen tarkastelulle maahanmuutto luo nopeasti muuttuvan ja hankalasti jäljitettävän kontekstin, mikä kyseenalaistaa mahdollisuuden yhteisön ja yksilön identiteettien rinnastamiselle.

Etnologinen ja antropologinen kuolinrituaalien tarkastelu on pitkään perustunut "primitiivisten" kansojen ja erilaisten etnisten ryhmien tutkimukseen. Nämä nähdään yhteisöinä ja sosiaalisina järjestelminä, ja rituaaleja tarkastellaan vastaavasti yhteisöllisinä prosesseina, joita sääntelevät yhteisön sosiaaliset tarpeet ja kulttuuriset mallit. Yksilö esiintyy tällaisessa tutkimustraditiossa ennen kaikkea yhteisöllisen perinteen kantajana ja käyttäjänä. Näin käsitettynä hautajaiset ovat siirtymärituaaleja, joilla merkitään ihmisen elämänkaaren suurimmat käännekohdat: syntymä, avioituminen ja kuolema. Vaikka siirtymärituaalit ovat syvästi yksilöllisiä ja ne liittyvät ihmiselämän tärkeimpiin muutoksiin, ne ovat myös yhteisöllisiä. Rituaaleissa korostuvat yksilön jäsenyys perheessä ja laajemmassa yhteisössä. Sekä yksilön että yhteisön näkökulmasta ihmiselämän käännetapahtumat koetaan kriisitilanteiksi, joita tulee rituaalin keinoin määritellä ja tasapainottaa uudelleen. (Esim. Malinowski 1960; van Gennep 1977; Turner 1977; Douglas 2001.)

Kuolema vaatii rituaalistamista, jotta sen aiheuttama kriisi voidaan ylittää. Aili Nenola $(1985,183)$ korostaa kuolemanritueelien vaiheittaista etenemistä. Ihmisen fyysistä kuolemista, ruumiin hävittämistä ja sosiaalista kuolemista ilmaistaan 


\section{Olga DaVydova}

ja eletään kuolemis-, hautaus- ja muistajaisrituaaleissa. Ensin mainittujen rituaalien keskipisteessä on yksilö, jälkimmäisissä sitä ovat jäljelle jäävät. Uuden tasapainon etsiminen on toiminnan pääsisältö. Nenola korostaakin jäljelle jääneen yhteisön sosiaalisten tarpeiden tärkeyttä rituaalisessa toiminnassa. Kuolemisrituaaleissa joudutaan ottamaan kantaa myös elämän eksistenssiin eli ihmiselämän perimmäisiin kysymyksiin: "Mistä ihminen tulee?", "Mihin hän menee?", "Miten on elettävä?" ja "Miten on kuoltava?" Siirtymärituaaleilla onkin läheinen suhde ihmisten maailmankatsomukseen ja perimmäisiin kysymyksiin. Nenola $(1985,183)$ esimerkiksi liittää elämänkäsityksen kuolemattomuuden kysymykseen. Hänen mukaansa kuoleman ongelman ratkaisu sisältää välttämättä uskon yksilön (ainakin määräaikaiseen) kuolemattomuuteen ja kuolemanjälkeiseen elämään. Lisäksi kuoleman tuomaan kaaokseen liittyy pybän ulottuvuus, joka ilmaistaan ja merkitään huolellisesti (Douglas 2001).

Kuolema nostaakin esille yhteisön tärkeimmät arvot. Laura Jetsu (2001, 34) tähdentää aunuksenkarjalaisten hautajaisrituaalin tutkimuksessaan elämisen ja kuolemisen välistä yhteyttä. Kuoleman malli on eräänlainen negaatio elämisen mallista. Kun tarkastellaan hautaamisrituaalin mallia ja sen logiikkaa, on mahdollista päästä perille myös elämisen mallista ja päätyä viime kädessä maailmankuvan jäljille. Kuvaamiani hautajaisia voi tarkastella tästä näkökulmasta: "Mikä on luterilaissuomalaisen hautausrituaalin malli?" ja "Missä suhteessa se on rituaaliin osallistuneiden ihmisten maailmankuvaan?" Tällainen kysymysasettelu implikoi yhtäältä osallistujia, jotka on ymmärrettävä yhtenäiseksi yhteisöksi, toisaalta se tuo esille rituaalin koherenttisuuden ja siinä tapahtuneet repeämät. Tällainen tarkastelunäkökulma edellyttää normatiivisten ryhmäidentiteettien olemassaoloa.

Hautajaisia voi pitää myös sosiaalisena tapahtumana, jossa identiteettejä luodaan performatiivisesti, kontekstuaalisesti ja prosessinomaisesti. Stuart Hallin (1999, 248-250) mukaan identiteetti on tietoinen, tulevaisuuteen suunnattu strategia, joka palvelee yksilön tai ryhmän pyrkimyksiä. Subjekti ei tietystikään pysty valitsemaan tai vaihtamaan identiteettiä täysin mielivaltaisesti, vaan siihen vaikuttavat monimutkaiset valtasuhteet ja yksilöiden elämänhistoria. Toisaalta kontekstikaan ei yksistään luo identiteettejä. (Alasuutari 2004, 134). Yleistäen voidaan sanoa, että postmodernin subjektiuden teorioissa yksilö on vapautettu yksittäisen, olemuksellisen ja kiinteän identiteetin pakosta. Hall (1999, 248-250) määrittelee identiteetin muodostumisen jatkuvaksi diskursiiviseksi prosessiksi, identifikaatioksi, jossa identiteetti muokkautuu riippuen siitä, kuinka subjektia representoidaan, mitä identiteettipositioita subjektille tarjoutuu ja mitä hän pystyy ottamaan haltuun. Identifioitumisessa subjekti muodostuu tietyssä paikassa ja ajassa ja tietyin välinein. 


\section{Paluumuuton konteksti ja IDEnTiteetin mäÄRITTtely}

Entisen Neuvostoliiton suomalaisten paluumuuttokäytäntö ja -lainsäädäntö kuvastavat kiinnostavalla tavalla suomalaisessa yhteiskunnassa käytäviä neuvotteluja suomalaisundesta. Keskustelu muodostaa pohjan yhteiskunnalliselle ja kansalliselle osallisuudelle. Paluumuutto-oikeus liittyy lähtökohtaisesti Suomen kansalaisuuteen, sillä periaatteessa vain Suomen kansalaisella tai hänen jälkeläisillään seuraavassa polvessa on oikeus kaikissa olosuhteissa palata Suomeen. Kun presidentti Mauno Koivisto televisiohaastattelussaan huhtikuussa 1990 tunnusti inkerinsuomalaiset kovia kokeneiksi suomalaisiksi, hän liitti heidätkin suomalaisuuden piiriin ja oikeutti heidät paluumuuttoon, vaikka nämä eivät koskaan ole olleetkaan Suomen kansalaisia.

Myöhemmässä keskustelussa ja lainsäädäntötyössä suurin huomio onkin kiinnittynyt nimenomaan inkerinsuomalaisten suomalaisuuden määrittelyyn. Se alettiin määritellä suomalaisen syntyperän kautta. Alussa riitti, että henkilön yksi isovanhempi oli ollut todistetusti suomalainen. Myöhemmin tätä vaatimusta tiukennettiin, ja nykyään hakijalla pitää olla ainakin kaksi suomalaiseksi rekisteröityä isovanhempaa. Vuodesta 1996 alkaen "suomalaista syntyperää olevilta" alettiin oleskeluluvan myöntämisen edellytyksenä vaatia osallistumista maahanmuuttovalmennukseen, jossa opiskellaan lähinnä suomen kieltä. Tämän takana on suomalaisuuden määrittely suomalaisen identiteetin kautta (Lepola 2000, 348-354).

Erilaisissa asiakirjoissa suomalaista identiteettiä ruvettiin korostamaan muuton perusteena. Esimerkiksi Hallituksen selonteossa inkerinsuomalaisten maahanmuntosta (1998) todetaan: "[P]aluumuuttajat ovat Suomeen muuttavia ulkosuomalaisia. Viimeksi mainitut puolestaan ovat ulkomailla asuvia Suomen kansalaisia tai suomalaista syntyperää olevia ulkomaan kansalaisia, jotka pitävät itseään suomalaisina eli joilla on suomalainen identiteetti. Suomalaisen identiteetin tunnusmerkistönä voidaan pitää tietoisuutta suomalaisesta syntyperästä ja sen julkituomista sekä esimerkiksi tapojen, perinteiden ja uskonnon vaalimista, osallistumista ulkosuomalaisten kulttuuri- ja järjestötoimintaan, yhteyksien ylläpitämistä Suomeen ja Suomessa asuviin, Suomen olosuhteiden ja tapahtumien seuraamista, suomen tai ruotsin kielen taidon ylläpitämistä ja siirtämistä seuraaville sukupolville jne.” (Inkerinsuomalaisten... 1998, 2-3.) Vaikka tässä määritelmässä suomalaista identiteettiä ei sidota eksplisiittisesti kielitaitoon, käytännössä nimenomaan suomen osaamisesta on tehty eräs tärkeimmistä kriteereistä punnittaessa inkerinsuomalaisten paluumuuttokelpoisuutta. Vuodesta 2001 alkaen maahanmuuttovalmennuksessa hankittavan kielitaidon on oltava ainakin auttava. Uudessa Ulkomaalaislaissa (2003) kielitaitovaatimus on kirjattu lain tekstiin, ja vaatimustasoa on tiukennettu. Lakiin on määritelty vaadittava kielitaitotaso, ja kielikokeen järjestäjänä on Suomen valtio. Kielitaitovaatimus koskee vain niitä, joiden suomalaisuus määräytyy suomalaisen syntyperän eikä Suomen vanhan kansalaisuuden kautta. Inkerinsuomalaisten 


\section{Olga DaVYDova}

suomalaisuuskin on määritelty suhteella Suomen valtioon. Ensisijainen muutto-oikeus on myönnetty niille, jotka ovat olleet toisen maailmansodan aikana evakuoituina Suomessa tai jotka ovat palvelleet Suomen armeijassa.

Vaikuttaakin siltä, että Venäjän suomalaisten kohtelussa paluumuuttajina Suomen kansalaisuuden merkitys suomalaisuuden käsittämisessä on kasvanut. Tämä on ilmennyt myös vuonna 2003 hyväksytyn uuden Kansalaisuuslain yhteydessä. Suomen kansalaisten jälkeläiset eli ne, joiden vanhemmat tai isovanhemmat ovat tulleet Neuvosto-Venäjälle "punapakolaisina", "loikkareina" tai Pohjois-Amerikan kautta, ovat voineet muuttaa vähemmällä odotusajalla kuin inkerinsuomalaiset, joiden paluumuuttojono on ollut ainakin Karjalan tasavallassa liikkumatta muutaman viime vuoden ajan.

Suomessa käytävä paluumuuttajia koskeva keskustelu - erityisesti muutokset suomalaisuuden uudelleenmäärittelyssä ja sitä kautta Suomen maahanmuuttopolitiikassa ja -käytännöissä - vaikuttaa myös Venäjällä käytävään suomalaisuuskeskusteluun ja suomalaisuuden ymmärtämiseen. Olen seurannut tilannetta Karjalassa, jonka suomalainen väestö on heterogeenisempaa kuin Leningradin alueen tai Viron. Karjalan suomalaiseksi rekisteröity väestö on muodostunut useiden muuttoprosessien tuloksena. Punapakolaiset saapuivat Suomen vuoden 1918 sisällissodan ratkettua, ja amerikansuomalaiset ja niin sanotut loikkarit muuttivat 1930luvulla. Inkerinsuomalaisten massamuutto Karjalaan ajoittuu sodanjälkeiseen aikaan, vaikka esimerkiksi inkerinsuomalaisia opettajia tuli Karjalaan jo ennen sotia, samoin kuin poliittista valistustyötä tekeviä "suomensuomalaisia" Inkerinmaalle. Inkerinsuomalaisten ja suomen- ja amerikansuomalaisten välillä on usein ollut jännitteitä, mikä on kuitenkin esitetty pikemmin "vanhoillisten" ja "uudistusmielisten" välisenä konfliktina kuin erilaiset taustat omaavien suomalaisten välisenä kitkana (Pakkanen 1992, 92). Paluumuuttojärjestelmä on asettanut inkerinsuomalaisuuden ja Suomen kansalaisuuteen sidotun suomalaisuuden eriarvoiseen asemaan, vaikka alun perin suomalaisen syntyperän -käsitteen oli tarkoitus asettaa ryhmät tasavertaisiksi. (Voutilainen 1995.) Keskustelua paluumuuttojärjestelmän hierarkisoivista vaikutuksista ei ole suodattunut paljon julkisille foorumeille, vaikka Petroskoissa julkaistavassa Carelia-lehdessä inkerinsuomalaisuutta ja Suomesta ja Amerikasta tulleiden suomalaisten suomalaisuutta on pohdittukin. Niitä on vertailtu sekä keskenään että suhteessa kärsimyksen, paluumunton, venäläisyyden ja Suomen suomalaisunden teemoihin. (Ks. Eklund 1995; Kolomainen 1994 ja 1995; Flink 1997; Davydova 2004, 262-272.)

Petroskoissa muuttovalmennuskursseilla keväällä 2000 tekemissäni haastatteluissa paluumuuttoon oikeutetut eritaustaiset suomalaiset ovat sen sijaan verranneet ja arvottaneet suomalaista syntyperäänsä, sen "aitoutta" ja "puhtautta" pohtiessaan, miksi toiset pääsevät muuttamaan nopeasti ja toisten muutto on muuttumassa yhä epämääräisemmäksi. (Ks. Davydova 2003; Davydova \& Heikkinen 2004; Davydova 2004, 189-283.) Floya Anthias $(2002,492)$ korostaa maahanmuuttajien identiteettikertomuksia käsittelevässä artikkelissaan, että on tärkeätä erottaa toimijoiden itsensä käyttämät identiteettikäsitykset tutkijan teoreettisesta viitekehyksestä ja tarkasteltava, mitä asiantiloja valmiit käsitykset saavat aikaiseksi ja mitä tekevät 
mahdottomiksi. Suomen viranomaisten paluumuuttomenettelyssä käyttämä identiteettikonsepti on ilmeisen essentialisoiva, kansallisuutta olemuksellistava. (Lepola 2000, 328-372.) Suomalaisen syntyperän odotetaan määräävän henkilön identifioitumista kulttuurisellakin tasolla. Aikaisemmassa tutkimuksessani (Davydova 2003, 2004) olen tuonut esille, että paluumuuttoa odottavien Venäjän suomalaisten puhetavat luovat biologiseen periytyvyyteen perustuvaa essentialisoitua suomalaisuutta. Toisaalta on tullut esille myös oman erikoislaadun korostamista esimerkiksi vertailuin suomalaisiin sukulaisiin; on puhuttu pyrkimyksestä säilyttää lasten venäjän kielen taito vielä Suomessakin; on arvioitu neuvostomenneisyyden myönteisiä puolia. Identifioitumiselle oli jätetty liikkumavaraa. Viranomaisten luokittelevia ja eriarvoistavia käytäntöjä on sekä vahvistettu että kyseenalaistettu. Paluumuuttajat ovat liikkuneet monissa kansallisuutta käsittelevissä diskursseissa ja luoneet monitasoista identifioitumista.

Paluumuuttajien syntyperistä riippumatta Suomessa heidät kuitenkin nähdään stereotyyppisesti "venäläisinä", "inkeriläisinä" ja "ongelmallisina". Suomalaista syntyperää olevat venäjänsuomalaiset ja heidän perheenjäsenensä ovatkin etupäässä venäjänkielisiä, jotka Suomeen muutettuaan vahvistavat vaietuksi sanottua (Pietikäinen \& Laihiala-Kankainen 2004, 10) venäjänkielistä vähemmistöä.

Karjalan tasavallan suomalaista syntyperää olevat ihmiset ovat siis eri aikoina ja eri keinoin Venäjälle tulleiden jälkeläisiä. Vain vanhemmat, etupäässä 19201940-luvulla syntyneet, ovat monoetnisistä avioliitoista. Mitä nuorempi henkilö on, sitä todennäköisemmin hän on syntynyt niin sanotussa seka-avioliitossa ja on venäjänkielinen, samoin kuin ovat heidän puolisonsa ja lapsensa. (Kozhanov \& Jalovitsyna 1998, 157-167.) Kuitenkin suomalainen syntyperä näyttää olevan tärkeä tekijä yksilön identifioitumisessa paluumuuton kontekstissa. Muina identiteettisymboleina voivat esiintyä vaikkapa venäjänkielisyys, "venäläinen kulttuuri" tai elämäntapa kahden tai useamman maan ja kulttuurin rajatilassa. Venäjänkielisyys ja venäläisyys kuuluvat luonnollisesti paluumuuttajien arkeen ja identifikaatioskaalaan. Tältä pohjalta lähden jatkossa tarkastelemaan venäläistä hautajaistraditiota. Venäjää käsiteltäessä on pidettävä mielessä, että yhteiskunnassa on ilmennyt jo noin kahden vuosikymmenen ajan siirtymistä neuvostoajan tiukasta sääntelystä kohti monimuotoisempaa yhteiskuntaa (ks. tarkemmin Hakamies 1998; Kachkin 2000).

\section{Neuvostoajan viralliset haUtajaiset}

Noin 90 prosenttia Karjalan tasavallan suomalaisiksi rekisteröidyistä ihmisistä asui vuoden 1989 väestölaskennan mukaan kaupungeissa, etupäässä Petroskoissa (Kozhanov \& Jalovitsyna 1998, 147). Näin ollen suurin osa paluumuuttajinakin Suomeen tulevista on ensimmäisen, toisen tai jopa kolmannen polven kaupunkilaisia. Yritinkin etsiä artikkeliani varten venäjänkielisiä kaupunkihautajaisia käsitteleviä tutkimuksia. Tämä osoittautui luultua vaikeammaksi tehtäväksi, sillä ainakin 1930-1980-luvuilla totalitaarisen valtion ideologisen kontrollin olosuhteissa pe- 


\section{Olga DaVYDova}

rinteen vapaa tallentaminen ja tutkiminen on ollut mahdotonta. Kaupunkifolkloren ominaisuutena pidetään sen ajankohtaisuutta ja kykyä reagoida poliittisiin, ideologisiin ja yhteiskunnallisiin muutoksiin. Sekä työväen keskuudessa elävää ja nopeasti muuttuvaa kaupunkifolklorea että kirjallisen kulttuurin ja maalaisväen suullisen perinteen kanssa vuorovaikutuksessa olevaa dynaamista lorea ja tapakulttuuria ruvettiin tallentamaan ja tutkimaan Venäjällä jo 1900-luvun alussa, mutta neuvostoajalla 1930-luvulta alkaen se oli hankalaa. (Nekljudov 2003,16.)

Tämä ei tarkoita, etteikö Neuvostoliitossa olisi lainkaan tallennettu ja tutkittu kaupunkikulttuuria, mutta esimerkiksi uskonnolliseen maailmankatsomukseen viittaavat elementit ovat tehneet rituaalien tallentamisen ja tutkimisen vaikeaksi. Marginaalisen ideologian eli uskonnon läsnäolo on siirtänyt rituaalien tutkimuksen neuvostoyhteiskunnan reuna-alueille. Neuvostoaikana hautajaistradition tutkiminen keskittyikin ensisijassa maaseudulla asuviin etnisiin ryhmiin ja menneeseen aikaan (esim. Suurhasko 1985; Konkka 1980) tai ideologiseen juhlaperinteeseen (Heikkinen 1985, artikkelissa mainitut). Neuvostoaikana perinteen tutkimus toteutui virallisen ideologian uomassa, minkä vuoksi ei ole yllätys, että parhaimmat neuvostoajan hautajaiskuvaukset löytyvät kaunokirjallisuudesta ja elokuvista (ks. esim. Dovlatov 1995, 297-316; Kaledin 1987, 5-77). Niissä kuvataan sekä virallisen kaavan mukaisia että epävirallisia hautajaisia. Neuvostoaikaisesta ideologisesta kontrollista vapauduttuaan nykyvenäläinen tutkimus hakeekin uusia lähestymistapoja perinteen ja folkloren tutkimukseen ja määrittelyyn (ks. esim. Bogdanov 2001, 5108).

Neuvostovaltion kehittämää ateistista hautajaisrituaalia on houkuttelevaa esittää jotenkin irrallisena aikaisemmasta perinteestä ja täysin vallankumouksen jälkeiseen aikaan sijoittuvana. Kuitenkin ensimmäiset merkittävät ei-kirkolliset siviilihautajaiset vietettiin Venäjällä vuonna 1877, kun Pietarissa haudattiin runoilija Nikolai Nekrasov. Menot olivat ortodoksiset, mutta arkun saattueesta oli muodostunut hautajaiskulkue. "Kulkuetyyppiset" hautajaiset alkoivat yleistyä vasta myöhemmin vuoden 1905 vallankumoustapahtumien yhteydessä. Siviilihautajaiset toimitettiin joko täysin irrallisina kirkosta tai yhdistettyinä kirkolliseen siunaukseen. Niiden ominaispiirteiksi muodostuivat arkun edessä pidettävät juhlapuheet, vallankumouslaulut hautajaiskulkueen aikana ja punaisen värin näkyvä käyttö (Kremljova 1999, 530).

Uusia neuvostorituaaleja ruvettiin luomaan heti vallankumouksen jälkeen. Tämä prosessi on ollut välillä vilkkaampaa (1920- ja 1950-luvuilla), välillä hitaampaa (1930-1940-luvulla). T. Makashina $(1995,154)$ esittää, että valtion harjoittaman luomistyön tulokset, juhlien skenaariot, ovat kiinnostavaa tutkimusaineistoa, sillä niitä voidaan käyttää Neuvostoliiton sosiaalisten, taloudellisten ja kansallisten prosessien peilinä. Niistä kuvastuu valtion ideologiaan perustuva kulttuuripolitiikka. Neuvostoliiton juhlaperinnettä koskevassa artikkelissa Kaija Heikkinen (1985) on kuvannut neuvostoperinteen tietoista luomista "esteettisen folklorismin" keinoin. Uuden perinteen piti vastata yhteiskunnan ideologisia arvoja ja olla muodoltaan kansallista mutta sisällöltään sosialistista. Kun ideologia oli ateistinen, perimmäinen näkemys ihmisestä poikkesi kristillisestä. Elämän käännekohtien käsittely, 
siirtymäriitit, oli saatava pois kirkon hallusta. Hautajaismenojen metafyysinen sisältö - elämän loppu, sielun erottuminen maallisesta, elollisen muuttuminen elottomaksi - oli siirrettävä materialistiselle ja uudelle symboliselle pohjalle. Ihmisen elämän tärkeimpänä referenssinä alkoi esiintyä ihmisen suhde yhteiskuntaan. Vastaavasti korostuivat sellaiset seikat kuin työ, suhde valtioon ja näkemys omasta merkityksestä historian kulussa (Heikkinen 1985, 123).

Kaija Heikkisen (1985, 128-129) siteeraama hautajaisten skenaario on valmistettu 1970-luvulla Ukrainan SNT:n asettaman komission suosituksena hautajaisten järjestäjille, mutta samalla kaavalla hautajaisia on järjestetty ympäri Neuvostoliittoa. Hautajaisskenaario on yksityiskohtainen, sillä siinä määritellään tapahtumapaikka, juhliin osallistuvat henkilöt ja tahot, heidän työtehtävänsä ja itse tapahtuman eteneminen:

\section{Vainajan hyvästely}

tapabtun kotona tai työpaikalla koristeluin ja erilaisin symbolein rituaalitilaksi tehdyssä paikassa, lattialla on avonainen arkeku, vainajan työtä ja ybteiskunnallista toimintaa symbolisoivat kunniamerkit on asetettu arkun viereen, arkun äärellä on komission jäsenistä muodostettu kunniavartio, soitetaan surumusiik.kia, jonka aikana omaiset byvästelevät vainajan. / Vainajan kantaminen pois. Ark.ku kannetaan ulos surumusiikin soidessa. Edessä kannetaan suruasennossa olevaa lippua, jossa on mustat surunaubat, sitten tulee vainajan valokuva, seppeleet, kunniamerkit, sitten arkun kansi ja lopuksi arkku.

\section{Surukulkue}

Jos kulkue etenee autoilla, ensin menee auto, jossa on katafalkilla arkeku ja vainajan valokuva, kunniamerkit ja lippu. Sitten menevät omaisten ja muun saattoväen autot. Sopimuksen mukaan orkesteri tai kuoro ottaa hautausmaan porteilla kulkueen vastaan. Matkan varrella pysähdytään sen rakennukesen kohdalle, jossa vainaja oli asunut tai työskennellyt.

\section{Siviilipanikiida}

tapabtun joko hautausmaalla, erityisessä surutalossa tai suruaukiolla hautausmaan vieressä. Tilaisunden avaa komission pubeenjohtaja tai organisaattori mikäli komissiota ei ole muodostettu. Seuraavat muistopubeet. Pubeiden välillä soitetaan surumusiikkia. Pubeiden päätyttyä komission pubeenjohtaja julistaa: "Kunnianosoituksen, nöyryyden ja surun osoitukeseksi kumarramme Neuvostoliiton kansalaiselle valtion lipulla." [..]

\section{Haudalla}

omaiset byvästelevät vainajan, peittävät kasvot liinalla ja sulkevat arkun. Hautausmaan työntekijät tai hautajaisiin osallistuvat (mutta ei koskaan omaiset) laskevat arkun hautaan. Omaiset ja muntkin hautajaisiin osallistuvat heittävät hautaan biukan maata viimeisenä kunnianosoituksena vainajalle. / Soitetaan surumusiikkia. / Hautakummulle sijoitetaan tilapäisesti muistotaulu, jossa on vainajan nimi ja valokuva, samaten kukkia ja seppeleet. Hautausmaalle tuodut vainajan kunniamerkit pidetään joko vainajan perheessä tai ne luovutetaan paikalliseen neuvostojen taloon. 


\section{Olga DaVYDova}

\section{Muistajaiset \\ Yleisen tavan mukaan vainajan omaisetjärjestävät tämän jälkeen muistajaiset.}

Tämäntyyppiset skenaariot olivat Makashinan (1995, 162-163) mielestä kaavamaisia ja kaukana todellisesta elämästä. Niitä ei osoitettu kenellekään konkreettisesti. Niiden piti toimia juhlien kaavoina kaikissa sosiaalisissa ryhmissä ja kaikkialla Neuvostoliitossa, niin maaseudulla kuin kaupungissakin. Makashina suhtautuu kriittisesti myös yrityksiin lisätä juhlaskenaarioihin kansallisia piirteitä. Hänen mielestään skenaarioita kirjoittaneet ihmiset eivät olleet kansanperinteen asiantuntijoita eivätkä ymmärtäneet kansanperinteen logiikkaa. Kansalliset elementit olivat pikemmin dekoratiivisia lisäyksiä tapahtuman yleiseen runkoon. Juhlat suunniteltiin pidettäviksi julkisilla paikoilla suuren väkijoukon ollessa läsnä. Neuvostoideologian mukaisten perhejuhlien siis piti olla yhteiskunnallisia "perhe on yhteiskunnan solu" -periaateella.

Heikkisen esittämää skenaariota voi sanoa ateistiseksi. Arno Survo (2001, 32) korostaa kuitenkin, että neuvostokauteen usein sovellettavat luonnehdinnat - esimerkiksi ateismi ja neuvostoliittolaisuus - ovat sellaisenaan tyhjï selitysmalleja. Attribuutti “virallinen” kertoo paremmin ateismin merkityksestä arkipäivässä. Lapsuudenkotini sijaitsi Petroskoin kaupungin ja Suolusmäen hautausmaan rajamailla. Hautajaismarssit kuuluivat meille varsinkin kauniina kesäpäivinä, ja kauppareissulla saattoi nähdä hautajaiskulkueita. Luulen, että skenaariossa esitetty tapa oli käytössä varsinkin merkittävässä sosiaalisessa asemassa olevien henkilöiden hautajaisissa. "Tavallisten ihmisten" hautajaisissa sitä sovellettiin vain osittain. Skenaarion mukaiset hautajaisrituaalit olivat näkyviä ja julkisia kun taas kuolemis- ja muistajaisrituaalit kuuluvat yksityiseen alueeseen. Sääntely ja kontrolli ulottuivat niihin vähemmässä määrin, ja siksi niissä noudatettiin myös epävirallisia uskonnollisia tapoja. Varsinaista tutkimustietoa tästä aiheesta on kuitenkin vaikea löytää.

\section{EpäVIRALliset HAUTAJAISET}

Elämän käännekohtien käsittely on ollut Venäjällä kirkkokuntien hallussa 1900luvulle saakka. Rituaalit on suoritettu uskonnollisen kaanonin mukaan. Venäläisen hautausrituaalin pohjana ovat ortodoksiset menot, jotka kansankulttuurissa olivat muokkautuneet omanlaisiksi lukuisten tapojen ja uskomusten vaikutuksesta (Kremljova 1999, 517). Unelma Konkka (1980, 31) mainitsee, että kaikista kansan harjoittamista siirtymäriiteistä parhaiten olivat neuvostoaikana säilyneet nimenomaan hautajais- ja muistajaismenot.

Neuvostoajan jälkeiseltä ajalta hautajaisperinteen tutkimuksia on vain muutamia. Nina Lavonen (1995) ja Laura Jetsu (2001) ovat tutkineet aunuksenkarjalaisten maaseutuhautajaisia 1990-luvulla, ja V.F. Shevchenko (2003) on kerännyt samoihin aikoihin hautajaisia koskevaa muistitietoa Volgan varrella sijaitsevalla Uljanovskin alueella. Shevchenkon artikkelissa ortodoksia esiintyy hautajaisperin- 
teen erottamattomana osana. Heti alussa ilmoitetaan, että sekä vainajat että haastatellut ovat olleet joitakin poikkeuksia lukuun ottamatta venäläisiä ja ortodoksiseen uskontoon kastettuja. Jotkut heistä olivat jopa lukijanaisia eli hautajaisten asiantuntijoita. Kaikki haastatellut asuivat kaupungissa, mutta heitä ei suinkaan voida Shevchenkon mukaan pitää täysin kaupunkilaisina, sillä he olivat syntyneet maaseudulla. Kuvatut hautajaismenot eivät myöskään sijoitu ainoastaan kaupunkiin. Haastateltavat ovat kertoneet sekä omista kokemuksistaan että uskonnollisesta kirjallisuudesta ja muuta kautta hankitusta tiedosta. Shevchenkon mukaan artikkelissa esitetty materiaali antaa kuvan nykyajan hautajaisista ja muistajaisista sekä traditionaalisina että samaan aikaan eklektisinä. Niissä sekoittuu erilaisia alueellisia ja etnisiä aineksia, ortodoksisia ja neuvostoaikaisia menoja. Olin yllättynyt, että Lavosen, Jetsun ja Shevchenkon kuvaamista menoista löytyi niin paljon yhtäläisyyksiä, huolimatta pitkästä välimatkasta ja tutkittujen ryhmien erilaisesta etnisestä taustasta.

Kuolemaan liittyvä rituaalikompleksi on jaettu Shevchenkon artikkelissa vaiheisiin (1). Seuraavassa esitän hänen artikkelinsa pohjalta konstruoidun hautajaiskuvauksen:

\section{Kuolemaa \\ tekevä valmistautuessaan kuolemaan pyrkii byvästelemään sukuaan ja läheisiään. Joskus kuo- levan luo voidaan kutsua pappi vïmeistä voitelua varten, tai lukea Hengenpäästörukous. Kuol- leelta suljetaan silmät, ikonin eteen sytytetään tuohus tai lampukka, ja tuli pyritään pitämään yllä seuraavat 40 päivää. Naiset panevat päälleen tummia vaatteita. Kaikeki kiilttävät pinnat pyritään verhoamaan, ettei niistä heijastuisi sattumalta kuolleen sielu. Joskus avataan ikkuna. Ovi pidetään lukitsematta aina. Kun ruumis on vielä lämmin, se pestään lattialla samalla lakanalla, millä vainaja on kuollut. Tämän tekevät ainoastaan naiset, joko varta vasten kutsu- tut pesijät tai naapurit tai sukulaiset (tytär, miniä). [..]}

\section{Ruumis}

asetetaan laudalle jakekaroiden varaan jalat oveen päin kunnes tuodaan ruumisark.ku. Ruumïn siirtämisestä ark.kun vastaavat miehet: sukulaiset tai arkun tuoneet rituaalitoimiston työntekijät. [..] Naapureita ja tuttavia alkaa käydä vainajan kodissa jättämässä byvästejä. Monet tuovat "hautajaisrahaa" [..]. Usein kutsutaan "lukijamummoja" lukemaan psalttaria ja laulamaan hengellisiä lauluja. Läheiset itkevät ja esittävät kuolinitkuja jos osaavat. Vainajan lähellä on oltava ibmisiä jatkuvasti. [..]

\section{Hautaus}

toimitetaan kolmantena vuorokautena kuolemasta. [..] Ruumis pyritään kantamaan ulos puolenpäivän maissa. Sitä ennen vainajalle jätetään byvästit, ja byvästelleet voivat olla menemättä hautausmaalle. [..] Ruumiinsiunausta ei toimiteta läheskään aina. Jos se tehdään, pappi kutsutaan siunaamaan kotiin, tai sitten matkealla hautausmaalle poiketaan kirkossa. Siunaus voidaan toimittaa myös ennen hautajaisia kirkossa siunatulla mullalla, ilman pappia. Vainajaa itketään jatkuvasti, varsinkin jos ibminen on kuollut nuorena tai traagisesti, pyritään esittämään kuolinitkuja ääneen. [..] 


\section{Olga DaVYDova}

\section{Hautausmaalla}

läheiset sukulaisetjättävät byvästit toistamiseen, vainajaa (tai ikonia) voidaan sundella ja pubutella. Joku ystävistä tai työkavereista pitää lopullisen jääbyväispubeen. Orkesteri soittaa koko ajan arkun naulaamiseen asti. Suljettu arkeku lasketaan hautaan liinoilla, jotka nostetaan sitten ylös ja kë̈tetään seuraavissa hautajaisissa. Arkun päälle beitetään multaa jääbyväisten merkkinä. Suljetun haudan päälle pannaan valokuva, kukkia ja seppeleitä. Hautapaikalta autoille mennään toista tietä. Paluumatkalla keskustellaan asioista, jotka eivät liity hautajaisiin.

\section{Muistajaisiin}

mennään suoraan hautausmaalta. Ne järjestetään vainajan tai hänen sukulaistensa kotona, tai ruokalassa. Joskus vainajaa aletaan muistella jo hautausmaalla, letuilla ja viinillä. Miehet voivat ottaa ryypytpaluumatkalla. [..] Hautajaisten jälkeen muistajaisia järjestetään yhdeksäntenä ja kahdentenakymmenentenäpäivänä (jolloin vainajatylittävätpalavan joen) - jälkimmä̈siä ei pidetä aina. Kirkossa voidaan tilata liturgia. Neljännenkymmenennen päivän muistajaisia pidetään pakollisina. Silloin jätetään byvästit sielulle, jonka uskotaan jättävän kodin. Järjestetään ateria (ja vainajalle laitetaan sama ateria kuin hautajaispäivänä), jonka jälkeen käydään hautausmaalla. [..] Seuraavat muistajaiset järjestetään puolen vuoden ja vuoden päästä k.uolemasta. Jatkossa muistamisen syynä voidaan mainita kuolleesta näbty uni tai joku enne. Hautausmaalla käydään sen jälkeen vainajan syntymä-ja kuolinpäivänä, vanhempainpäivinä ja pääsiäisenä. Hautaa käydään myös siivoamassa keväisin ja sykesyisin, että se näyttäisi hoidetulta. Hoitamaton bauta tulkitaan vanhempien unobtamisena, "omantunnon puuttumisena". (Shevchenko 2003.)

Edellä kuvattua kaavaa Shevchenko luonnehtii ortodoksis-kansanuskonnolliseksi. Verrattaessa kaavaa Heikkisen esittämään newvostoaikaisten hautajaisten skenaarioon paljastuu hautajaismenojen välinen yhteys. Neuvostoaikaisen rituaalin kaava pohjautui ortodoksiseen, ja nyky-ortodoksisissa hautajaisissa voi olla elementtejä neuvostoajalta. (2)

Artikkelin alussa kysyin, mikä hautajaismalli tuntuisi minusta, suomalaispuolalais-venäläistä syntyperää olevasta, pääosin Petroskoissa 1980-1990-luvuilla hautajaisissa käyneestä, omimmalta. Shevchenkon ja Jetsun kuvaamista menoista en tunnistanut - niiden kaikesta tuttuudesta huolimatta - moniakaan asioita omikseni. Toki kuoleman kulttuuri on Venäjällä ennen kaikkea vanhojen naisten hallussa (Jetsu 2001, 100-104), joten en voi iästäni johtuen toimia kuolemisen eksperttinä. Olen kuitenkin käynyt monissa hautajaisissa ja jopa järjestänyt yhdet. Mielestäni siviilihautajaisten traditio elää Venäjällä edelleenkin, vaikkei täysin neuvostoskenaarioiden märäämässä muodossa. Shevchenko kuvaa kuolinrituaalien muuttumista, ja Laura Jetsun työssä (2001) keskitytään ortodoksis-kansanuskonnollisen vuorovaikutuksen tunnistamiseen. Uskonnon ja uskon läsnäolo tutkittavien maailmankuvassa ja rituaaleihin osallistuva tiivis yhteisö ovat näiden tutkimusten lähtökohtana.

Vuonna 1995 järjestämissäni petroskoilaisen perheenjäsenen hautajaisissa uskonnollisuudella sen sijaan oli vähäinen sija, vaikka rituaalit etenivät Jetsun ja Shevchenkon kuvaaman kaavan mukaisesti. Kuolema oli tapahtunut kotona, jonne 
"toivoton potilas" oli lähetetty sairaalasta epäonnistuneen leikkauksen jälkeen. Kuolemasta ilmoitettiin viranomaisille, joiden toimesta ruumis vietiin ruumishuoneelle, missä se pidettiin hautajaisiin asti. Ruumishuoneen työntekijät suorittivat vainajan pesun, pukemisen ja arkkuun laittamisen. Hautajaisten järjestämiseen kuului asiointi rekisteritoimistoissa, hautapaikan hankinta kaupungin hautausmaalta ja haudankaivajien löytäminen. Arkku oli tilattu niin sanotusta rituaalitoimistosta, ja se oli musta. Hyvästely tapahtui hautajaispäivänä ruumishuoneen yhteydessä olevassa surusalissa, jonne oli tullut vainajan tunteneita ihmisiä. Perheenjäsenet istuivat avoimen arkun ääressä. Vieraat hyvästelivät vainajan ja esittivät samalla osanottonsa sekä laskivat tuomansa kukat avoimeen arkkuun. Surusaliin kutsuttiin myös ortodoksinen pappi siunaamaan vainajaa, koska tämä oli alkanut käydä kirkossa viimeisinä elinvuosinaan, vaikka ei sitä ennen ollut uskovainen, kuten ei muukaan perhe. Ortodoksinen pappi kieltäytyi ensin siunaamasta vainajaa, jolla oli "katolinen nimi”, mutta suostui sitten ja suoritti toimenpiteen. Hyvästelyn jälkeen siirryttiin ilman orkesteria katafalkkibussilla hautausmaalle. Haudan olivat kaivanneet vainajan entiset työkaverit. Hautausmaalla vainaja hyvästeltiin viimeisen kerran ja siellä pidettiin myös puhe. Hautaamisen jälkeen siirryttiin vainajan kotiin muistoaterialle. Muistajaisiin oli tullut vainajan sukulaisia, ystäviä ja naapureita niin paljon, että vieraat hädin tuskin mahtuivat pöytään. Vainajaa muistettiin puheissa, joissa häntä kuvailtiin perheen jäsenenä, ystävänä ja työtoverina. Muistajaisateria oli tavallista juhlaruokaa, jonka perheen sukulaisnaiset ja naapurit yhdessä olivat valmistaneet. He tarjosivat ruoan korostetun vaatimattomasti. Pöydässä ei käytetty teräviä esineitä, ja peilit oli verhottu tummalla kankaalla. Vainajalle laitettiin oma lautanen vodkaryyppyineen ja leivänpalasineen. Näiden tapojen noudattamista valvoivat muistajaisia valmistelleet naiset, jotka "tiesivät", miten hautajaisia on järjestettävä. Perheenjäsenten annettiin surra ja näyttää surunsa. Muistajaisissa nautittiin alkoholia ja ilmapiiri muuttui niin, että lopulta muisteltiin hauskojakin asioita vainajan elämästä. Pienet muistajaiset pidettiin tavan mukaan yhdeksäntenä ja neljäntenäkymmenentenä päivänä, mutta ruokaa haudalle ei ole koskaan viety.

\section{IDENTITEETTIPOLITIIKKA JA RITUAALI}

Pietarilaisen folkloristin Svetlana Adonjevan (2001,16-17) mukaan jotakin kuolemasta sijaitsee aina pyhän alueella. Näin oli myös Neuvostoliitossa, vaikka valtio olikin ottanut kuoleman haltuunsa. Neuvostoideologiassa pyhänä esiintyivät muiden muassa "yhteinen hyvä" ja "kansan onni”, millä tarkoitettiin yhteiskunnan hyväksi tehtyä neuvostovaltion rakennustyötä. Neuvostohautajaisten fraseologiassa korostui suuntautuminen eläviin, vainajan työn jatkajiin, jotka "eivät saa hairahtua tieltä" ja joiden on "elettävä eteenpäin”. Esimerkiksi seppelenauhojen kirjoitukset osoitettiin eläville, vainajan kunniamerkit asetettiin kaikkien nähtäväksi ja hänen kuvansa oli koko ajan läsnä. Hautajaisten visuaalinen ja toiminnallinen puoli korostivatkin vainajan yhteiskunnallista läsnäoloa. Hautajaisiin osallistujat esiintyi- 


\section{Olga DaVYDova}

vät ryhmänä, jonka yhden jäsenen poistuminen ei vaikuttanut työn jatkumiseen. Neuvostoajan rituaaleja analysoidessaan Adonjeva (2001, 125-154) korostaa, että kuoleman tehtävänä oli kehittää kansallistunnetta. Kulttuurisesti merkittäviä kuolemia - esimerkiksi kuolemaa vallankumouksessa, Suuressa Isänmaallisessa sodassa tai "kansan onnen puolesta" - pidettiin ennenaikaisina, mikä sisälsi implisiittisesti ajatuksen ikuisesta elämästä. Ennenaikaisesti kuolleet olivat uhreja, jotka uhrasivat elämänsä jälkipolvien hyväksi. Eloonjääneet olivat velkaa kaatuneille, joten heidät kasvatettiin elämään sekä itsensä että kuolleiden puolesta. Adonjevan mukaan velka kuolleille, "kansan palveleminen" ja kuolleiden työn jatkaminen olivatkin neuvostoihmisen kulttuurisia imperatiiveja. Samalla kommunismin rakentamisesta tehtiin "kaikkien" jakama pyhä asia; kuolemalla sakralisoitiin valtion ja kansakunnan ideologinen pohja ja yhtenäisyys. (3)

Ortodoksis-kansanuskonnollisista hautajaisista tulee esille toisenlainen käsitys ihmisestä ja kuolemattomuudesta kuin mitä sisältyy neuvostomallisiin virallisiin siviilihautajaisiin. Vainajan sielun uskotaan olevan läsnä kaikissa menoissa näkymättömänä; yhteys ei katkea hautaamisenkaan jälkeen, ja sielun elämä jatkuu tuonpuoleisessa. Tosin Shevchenko ei erittele nimenomaan ortodoksis-kirkollisia, kansanuskonnollisia tai neuvostoaikaisia piirteitä. Kysymys uskonnollisuudesta ja sen sisällöstä ei olekaan yksiselitteinen "ateismin jälkeisellä" Venäjällä. Kimmo Kääriäinen $(2004,96)$ esittää kiinnostavaa taustatietoa ortodoksisuuteen identifioitumisesta: "Valtaosa venäläisistä pitää itseään ortodoksina. Etnisistä venäläisistä ortodoksina itseään pitää peräti 86 \%. Ortodoksi on Venäjällä hyvin laaja käsite. Siihen liittyy Venäjälle tyypillinen ajattelutapa, jossa uskonto ja etnisyys liitetään toisiinsa. Ortodoksisuus on etniselle venäläiselle (russkij) luonnollinen uskonto samoin kuin islam tataarille tai buddhalaisuus burjaatille. Tätä osoittaa myös se, että puolet $(47 \%)$ ateisteista pitää itseään ortodoksina.” Kuitenkin usko perinteisiin kristillisiin opinkappaleisiin on suhteellisen vähäistä: esimerkiksi kuolemanjälkeiseen elämään uskoo vain $27 \%$ ja ylösnousemukseen $10 \%$ venäläisistä. Eikristilliset uskomukset ovat yleisiä, sillä astrologiaan ja magiaan uskoo lähes puolet venäläisistä (mts., 102, 124).

Nykyvenäläisissä hautajaisissa tulee esille uskonnollisuuden ja uskonnottomuuden sekä niihin liittyvän etnisyyden jännittynyt suhde. Arno Survon (2001) mukaan etnisyyden, uskonnollisuuden, antietnisyyden ja antiuskonnollisuuden diskurssit muodostivat neuvostoaikanakin monitasoisen dialogi-konfliktin, jossa neuvotteluja käytiin yhä uudelleen "oman" ja "vieraan" määrittelystä, samanaikaisesta mukaan ottamisesta ja poisrajaamisesta. Eritasoiset valtasuhteet olivat siinä mukana. "Rahvaasta" käytiin ideologista taistelua, mikä synnytti monenlaisia kulttuurisia keskuksia ja periferioita. Kuitenkin käytäntö on ollut - ja on edelleenkin monikielistä ja monimerkityksistä, ja se pakenee kaikkea pelkistämistä.

Yhteenvetona voi todeta, että uskonnollisuudesta riippumatta kuolema on nykyvenäläisessä yhteiskunnassa enemmän läsnä kuin suomalaisessa (Jetsu, 2001, 88). Sen hallinta on ennemmin perheen ja lähipiirin kuin esimerkiksi terveys- tai kirkkoviranomaisten asia. Naisten status rituaaliekspertteinä on korkea. Adonjeva (2003) esittää myös, että hautausmenojen uudistamista tapahtuu yleisiin traditioihin 
nähden periferiassa, muun muassa sosiaalisesti korkeammassa asemassa olevien parissa. Venäläisten sanomalehtien perusteella voisi väittää, että "länsimaalaistyyppinen" kaupallinen hautaustoimi on alkanut kehittyä Venäjällä palvelemaan ennen kaikkea varakkaiden väestöryhmien tarpeita. Hautajaiset ovat enenevässä määrin statussymboli. Toisaalta jatkuvista sotatoimista ja terrori-iskuista johtuen ennenaikainen sankarikuolema on Venäjällä koko ajan läsnä, ja se on jopa jossain määrin normaalistunut. Näyttää siltä, että sitä käytetään uudenlaisen, nykyvenäläisen kansallistunteen luomisessa. Sankarikuolema-aiheiset hautajaiset näyttävät tapahtuvan neuvostoaikaisin menoin. Mukana on tavallisesti suruorkesterit, suruseppeleet, paljon punaista ja mustaa väriä ja vainajan ansioita symboloivia esineitä kuten valtion kunniamerkkejä. Toisaalta ortodoksinen pappi siunaamassa traagisesti menehtyneitä vainajia alkaa olla vakiintunut hahmo tämäntyyppisten hautajaisten televisiouutisoinnissa.

Venäjän hautajaistraditio on siis moniäänistä, ja se tuo esille maan tosiasiallista monikulttuurisuutta. Totalitaarisen valtion ja ideologisen hegemonian väistyttyä ei voi enää puhua virallisista ja epävirallisista hautajaistavoista vaan pikemmin eri sosiaalisissa ja etnisissä ryhmissä elävistä tavoista. Moninainen nykyvenäläinen hautaamistraditio toteutuu erilaisena riippuen paljolti siitä, kuinka merkittävästä yhteiskunnallisesta tapahtumasta on kyse. Julkinen tila on samalla vallan tihentymä, oli se sitten fyysinen tai diskursiivinen. Siinä toistetaan ja uusinnetaan yhteiskunnallista järjestystä, kokemusta järjestyksestä ja puhtaudesta, erosta ja sen merkityksestä (ks. esim. Hautaniemi 2004, Douglas 2001). Yhteiskunnalliseen valtaan suhteessa olevat piirit järjestävät hautajaisia, jotka vastaavat ajankohtaisia käsityksiä yhteiskunnallisesti merkittävästä kuolemasta ja kansallisesta normista. Hautajaistapoja sanelevat tavallaan vahvat yhteiskunnalliset identiteetit - tai kulttuuriset imperatiivit (Adonjevan 2001, 2003). Ihmiset neuvottelevat identiteeteistään ja kulttuurisista imperatiiveista oman toimintansa kautta joustavasti.

\section{JOENSUULAISET HAUTAJAISET: IDENTITEETTINEUVOTTELUT}

Tässä vaiheessa haluan palata joensuulaisen paluumuuttajan hautajaisiin ja paluumuuton kontekstiin. Kiinnitän huomioni kuoleman julkisiin tiloihin, joissa identiteettineuvottelut mielestäni artikuloituivat (ks. myös Huttunen 2002, 50-51). Suomalainen hautausmaa on vahvasti kansalliseksi mielletty paikka. Hautausmaalla sijaitsevat sodissa elämänsä isänmaalle uhranneiden sankarivainajien haudat. Omaisten haudoilla käydään kansallisina juhlapäivinä, kuten esimerkiksi jouluna ja itsenäisyyspäivänä. Hautausmaiden ylläpito on seurakuntien käsissä. Myös varsinainen hautausrituaali on suomalaisessa yhteiskunnassa selvästi kirkon hallitsema. Luterilaisella ja ortodoksisella kirkolla on rituaalinen etuoikeus jäseniinsä nähden (Jetsu 2001, 87.) Maahanmuuttajan näkökulmasta kuolemaan liittyvä tila edellyttääkin tietynlaista toimintaa: hautajaistoimitus representoi suomalaisuutta paikan ja menojen lisäksi kielellisesti. Joensuussa julkinen tila ja tapahtuman ekspertit olivat lei- 


\section{Olga DaVYDova}

mallisesti suomalaisia. Toisaalta vainajan lempikappaleen esittäminen ja muutama pastorin lukema venäjänkielinen lause antoivat tunnustusta hautajaisväen venäläiselle taustalle. Kuitenkin suomalaisuuden ja venäläisyyden suhde tässä julkisessa tilassa näyttäytyi epäsymmetrisenä, vaikka määrällisesti venäjänkieliset olivat enemmistönä. Asetelma tasapainottui vasta muistajaisissa, joka pidettiin vainajan kotona venäläiseen tapaan ja venäjänkielisten vieraiden kesken.

Miksi vainajan perhe sitten oli valinnut kuvaamani hautajaistavan, vaikka olisi ollut täysin mahdollista järjestää ortodoksiset tai siviilihautajaiset. Keskustelussamme leski oli kertonut, että vainaja olikin ortodoksi, ja että hautakivi tuodaan myöhemmin Petroskoista. Voi olla, että luterilais-kirkolliset hautajaiset tuntuivat ainoalta oikealta tavalta haudata ihminen - niin kuin Suomessa kuuluu. Vaikeissa tilanteissa, joissa ihminen joutuu pohtimaan valintojaan, hän usein turvautuu instituution ajattelutapaan. (Douglas 1987.) Suomessa kirkko on luonteva hautajaisekspertti; Venäjällä tämä toimijuus kuuluu suvulle tai lähiverkoston (vanhoille) naisille. Toisaalta luterilainen kirkko toimii aktiivisesti paluumuuttajien parissa, joten kontakti kirkkoon on luonteva ja helppo. Luterilaisuus esiintyykin suomalaisuuskonstruktion "geneettisenä" osana sekä Suomessa että Suomen ulkopuolella (ks. Heikkinen 2003).

Kimmo Kääriäinen $(2004,96)$ on viitannut Venäjällä yleiseen tapaan liittää ihmisen etninen tausta etnisyydelle ominaiseen "perinteiseen" uskontoon, jolloin uskonto juontuu pikemminkin ihmisen etnisestä syntyperästä kuin maailmankatsomuksellisesta vakaumuksesta. Samanlainen ajattelutapa näyttää vallitsevan Suomessa paluumuuttoa ja (inkerin)suomalaisuutta määrittelevissä asiakirjoissa. Inkerinsuomalaisiin liitetään ongelmattomasti luterilaisuus, mikä ei välttämättä pidä todellisuudessa paikkaansa (ks. Heikkinen 2003). Kääriäisen mukaan valtaosa kansasta Venäjällä rakentaa omia eklektisiä käsityksiään eikä ole valmis sitoutumaan organisoituun uskonnollisuuteen ja sen edellyttämään normistoon. Tästä löytyy hyviä esimerkkejä haastatteluaineistostani. Eräs haastateltava, 1950luvulla syntynyt nainen, oli kastettu 1990-luvun alussa ortodoksiseen uskontoon, koska näin oli sanottu "hengellisessä koulussa". Hän pitää kuitenkin luterilaisia kirkkojuhlia "omina" suomalaisen syntyperänsä perusteella. Toinen oli kertonut uskontokunnan valinnasta tyttärelleen, kun tämä oli ollut 10-vuotias. Koska tytön isä oli karjalainen, olivat he ensin menneet ortodoksiseen kirkkoon, mutta nähtyään siellä epämiellyttävän näköisen papin, he olivatkin siirtyneet luterilaiseen kirkkoon suomalaisen äidin mukaisesti. Luterilaisuudesta suomalaisuuden symbolina kertoo myös monien paluumuuttajien pyrkimys liittyä Suomessa luterilaiseen kirkkoon "tullakseen suomalaisiksi".

Hautajaisten vainaja oli isänsä puolesta Suomen kansalaisen jälkelänen. (4) Uskon, että suomalaiset hautajaiset olivat perheeltä tietoinen valinta. Vainaja oli eläessään painottanut syntyperästään johtuvaa "oikeaa suomalaisuutta", minkä hän oli kuitenkin kokenut olevan ristiriidassa sen kanssa, kuinka hän oli menestynyt Suomessa. Suomen kielen opiskelu ei sujunut, ja mies oli pitkäaikaistyötön. Suomalaisittain pidettyjen hautajaisten voi tulkita olevan suomalaisuuden manifestaatio: julkinen identifioituminen suomalaisuuteen. Vainajan ongelmallinen suomalaisuus 
tuotiin esille julkisissa rituaaleissa viimeisen kerran. Tämä teko oli osoitettu sekä perheestä poistuvalle jäsenelle että perheen elämää jatkaville: miehen suomalaisuus ikään kuin lunasti hänen venäläisiksi luokiteltujen perheenjäsentensä jäämisen Suomeen.

Havaintoni mukaan hautajaisissa neuvoteltiin eksplisiittisin symbolein suomalaisuuden ja venäläisyyden suhteesta. Identiteettineuvotteluksi tulkitsisin myös vainajan perhettä koskeneet episodit. Vaikuttaa siltä, että Petroskoista hautajaisiin tullut vainajan äiti tunsi olonsa läsnäolevista kaikkein luontevimmaksi ja hän suri varauksetta. Hän ymmärsi papin surunvalittelut ilman tulkkaustakin. (5) Papin keskusteluyritys vainajan lesken kanssa taas ei mennyt odotetulla tavalla, sillä tämä oli vainajan toinen vaimo ja ensimmäinen vaimo istui tämän takana. Naisella ei ollut yhteisiä lapsia miehen kanssa, kun taas edellisellä vaimolla oli. Kun pappi kysyi lapsista, tilanne koettiin vaikeaksi. Rituaalin ekspertin olettamus normatiivisesta avioliitosta yhteisine lapsineen vaati selitystä, jota siinä tilanteessa ei haluttu kuitenkaan antaa. Toisen vaimon ja uusioperheen epävakaa asema tuli korostetuksi, ja tämä lisäsi vieraantuneisuuden tunnelmaa, kun taas poikansa menettäneen äidin kulttuurimalli sai vahvistusta.

Outi Fingerroos (2004) lähestyy Kannaksen hautajaistradition tutkimuksessaan kuoleman ongelman kollektiivista ratkaisua muistitiedon ja kertomusten kautta. Hänen mukaansa yhteisö määrittää luvallisen rituaalisen kertomuksen ja rooliodotukset, kuoleman normaaliuden tai epänormaaliuden. Luulen, että kuvaamassani tapauksessa hämmennystä synnytti myös kuoleman koettu epänormaalius. Mies oli kuollessaan keski-ikäinen ja kuolema oli ollut äkkinäinen. Kuten eräs mies sanoi hautajaisissa, "mehän tulimme Suomeen elämään, ei kuolemaan". Sen lisäksi venäjänkielinen maahanmuuttajayhteisö on hyvin heterogeeninen ja kokee asemansa kokonaisuudessa ristiriitaiseksi ja häilyväksi. (ks. Pietikäinen \& Laihiala-Kankainen 2004.) "Hautajais- ja kuolemannormia" ei ole vielä syntynyt, eikä venäläinenkään hautajaistraditio voi toimia vahvana referenssinä sen moninaisuuden vuoksi.

\section{JoHTOPÄÄTÖKSET}

Venäjältä Suomeen suuntautuvaa paluumuuttoa käsittelevä keskustelu rakentuu paluumuuttajien suomalaisuuden tai venäläisyyden eli heidän etnis-kulttuurisen identiteettinsä määrittelyn varaan. Tässä keskustelussa Suomi määrittyy etniskulttuuriseksi kansakunnaksi, jossa syntyperä ja kulttuuri liittyvät tiiviisti toisiinsa (ks. Lepola 2000). Maahanmuuttajien odotetaan kotoutuvan ja integroituvan suomalaiseen yhteiskuntaan, ja siinä prosessissa kulttuurisen muutoksen ja liikkeen odotetaan olevan yksisuuntaista. Paluumuuttajien kohdalla suomalaistumispaineet ovat erityisen vahvoja.

Artikkelissa on todennettu, että muuttoliikkeet ja kulttuuriset prosessit ovat luonteeltaan monimutkaisia ilmiöitä. Maahanmuuttajien luomien sosiaalisten tilojen ymmärtäminen ylirajaisina, kansallisvaltion kontekstit ylittävinä ja niiden 


\section{Olga DaVYDova}

kanssa jatkuvassa neuvottelussa muotoutuvina antaa mahdollisuuden käsittää kulttuuristen prosessien moniselitteisyyttä (ks. Bryceson \& Vuorela 2002). Transnationalismi merkitsee Petri Hautaniemen $(2004,167)$ mukaan perspektiivin vaihtoa eli irtautumista yksittäisen kansallisvaltiotutkimuksen perinteestä. Transnationalistinen tutkimus voi kyseenalaistaa monia normatiivisia, valtioiden sisäisiä yhteiskuntapoliittisia kysymyksenasetteluja. Tällaisen tutkimuksen lähtökohdat määrittyvät laajasti ymmärrettyjen rajojen ja rajanylittämisen problematiikasta kä$\sin$.

Olen analysoinut paluumuuttajan hautajaisia sosiaalisena tapahtumana, jolloin "rituaali ei vahvista eikä todista tapahtunutta tosiasiaa, vaan konstruoi, luo sitä, ja loppujen lopuksi on sitä (Baiburin 1993 via Adonjeva 2001, 9)”. En ole lähtenyt kyselemään vainajan perheen jäseniltä mitään. En myöskään ole halunnut tuoda konkreettisia ihmisiä esille. Sen sijaan olen kuullut, että muutkin paluumuuttajat ovat tehneet "virheitä" Suomessa pidetyissä hautajaisissa. Hautajaiset tuovatkin kaikessa emotionaalisessa latautuneisuudessaan esille paluumuuton kompleksisuuden, saumattoman identifioitumisen vaikeuden ja sen monisuuntaisuuden. Kuvaamani hautajaiset ovat mielestäni yksi esimerkki paluumuuttajien kommunikoinnista suomalaisuus- ja venäläisyyssymbolien ja -diskurssien kanssa, kansallisten identiteettien artikuloinnista, yhdistämisestä ja ylittämisestä eri valtasuhteiden vaikutuksen alla. Suomalaisuuden ja venäläisyyden välinen jännite on luonteenomaista paluumuuton muodostamalle ylirajaiselle sosiaaliselle tilalle. Tähän jännitteeseen joudutaan ottamaan kantaa konkreettisissa olosuhteissa. Puhuttaessa paluumuuttajien identiteeteistä on pyrittävä analysoimaan sekä niiden artikulointitapoja että konteksteja.

\section{VIITTEET}

1. Vaiheet ovat: kuolemaan valmistautuminen, hautaukseen valmistautuminen, matka hautausmaalle, hautaaminen ja muistajaiset.

2. Pietarilainen folkloristi Svetlana Adonjeva (2001, 61) esittää, että neuvostoajan juhlakalenteri oli luotu korvaamaan ortodoksisia juhlia. Ennestään pyhiksi miellettyjä päiviä käytettiin uusien ideaalien sisäistämiseksi.

3. Toisaalta merkittävä kuolema takasi kuolemattomuuden eli ikuisen elämän jälkipolvien muistoissa. Adonjeva tuo esille kuolemattomuuden käsittämisessä neuvostoaikana tapahtuneet muutokset. 1800-luvun sanakirjassa "kuolematon" viittasi ennen kaikkea hengen ikuiseen elämään, joka ei ole osallinen kuolemaan, kun taas vuoden 1948 sanakirjassa se tarkoitti ensisijaisesti ikuista olemassaoloa ihmisten muistossa. Adonjeva näkee tässä siirtymän ortodoksisesta maailmankuvasta neuvostomytologiaan. Sinänsä uhrautuminen jonkun pyhäksi mielletyn asian puolesta (kuolema isänmaan puolesta) kuuluu Benedict Andersonin (2001, 160 172) mukaan kansakunnan "kuvittelun" ja yhdistämisen oppiin.

4. Uskonnollisuus ei kuitenkaan ole "perinteistä" tässä ryhmässä. Punapakolaisina tai sosialismin rakentajina Neuvosto-Venäjälle muuttaneiden suo- 
malaisten keskuudessa vallitsi ennemminkin kommunistinen vakaumus (Takala 1998). Eräs haastateltavani oli sanonut äitinsä sukupolven olleen "vahvoja ihmisiä, jotka eivät uskontoa tarvinneet".

5. Äiti myös oli menettänyt poikansa, ja tämän traagisuuden kokemisen taustalla on monta yleismaailmallista mielikuvaa kuten esimerkiksi äidin ja pojan pyhä suhde (Jumalanäiti ja hänen Poikansa) ja "etteivät aikuiset lapset saa kuolla ennen iäkkäitä vanhempiaan”. Pojan menettänyt iäkäs äiti on suullisessa perinteessä ja kansallistunteen luomisessa yksi suosituimpia aiheita. Esimerkiksi monet neuvostoaikaiset sota-aiheiset laulut ja propaganda kehittivät sitä aktiivisesti. Hautajaiskeskusteluissa puhuttiin myös muunlaisesta, äidin kannalta traagiseksi koetusta asiasta. Poika oli kuollut ja hänet haudataan ulkomailla eikä "omassa maassa”, millä on yhteyksiä pyhäksi koettuun "äiti-synnyinmaahan”. (Ks. Rjabov 2001).

\section{TutKimusaineistoT}

\section{Haastattelut:}

Muuttovalmennuskurssilla olleiden paluumuuttajien haastattelut Petroskoissa keväällä 2000. Haastattelija: Olga Davydova.

\section{Muistiinpanot:}

Muistiinpanot petroskoilaisen paluumuuttajan hautajaisista Joensuussa alkuvuodesta 2004. Olga Davydovan hallussa.

\section{KiRjallisuUs}

ADONJEVA, SVETLANA 2001: Kategorija nenastojashtshego vremeni. (Antropologicheskie ocherki). Sankt-Peterburg: Peterburgskoe vostokovedenie.

— 2003: Pragmatika fol'klora i praktika perehodnyh ritualov. - Nekljudov, S. Ju. (red.), Souremennyi gorodskoi fol'klor. Moskva: Rossijskij gosudarstvennyi gumanitarnyi universitet.

- 2004: Pragmatika fol'klora. Sankt-Peterburg: Izdatel'stvo Sankt-Peterburgskogo universiteta.

ALASUUTARI, PERT'TI 2004: Social Theory and Human Reality. London: SAGE Publications.

ANDERSON, BENEDICT 2001: Voobrą̧haemye soobshtshestva. Rąmyshlenija ob istokah i rasprostranenii nacionalizma. Moskva: Kanon-Press-C.

ANTHIAS, FLOYA 2002: Where do I belong? Narrating Collective Identity and Translocational Positionality. - Ethnicities 4(2), 491-514.

BAIBURIN, A.K. 1993: Nekotorye obshchie soobrąhenija o rituale. Moskva: Aeqinox MCMXCIII 


\section{Olga DaVydova}

BOGDANOV, KONSTANTIN 2001: Povsednevnost' i mifologija. Sankt-Peterburg: "Iskusstvo-SPB".

BRYCESON, DEBORAH \& VUORELA, ULLA 2002: Transnational Families in the Twenty-first Century. - Bryceson, Deborah \& Vuorela, Ulla (eds.), The Transnational Family. New European Frontiers and Global Networks. Oxford: Berg. DAVYDOVA, OLGA 2003: Syrjivä ja sisäänsulkeva suomalaisuus paluumuuttajien puheessa. - Simola, Raisa \& Heikkinen, Kaija (toim.), Monenkirjava rasismi. Joensuu: Joensuu University Press.

— 2004: Etnisyyspube Suomen kynnyksellä. Paluumunttajien suomalaisunden muodostuminen. Julkaisematon perinteentutkimuksen lisensiaattitutkielma. Joensuu: Joensuun yliopisto, Suomen kielen ja kulttuuritieteiden laitos.

DAVYDOVA, OLGA \& HEIKKINEN, KAIJA 2004: Produced Finnishness in the Context of Remigration. - Puuronen, Vesa \& Häkkinen, Antti \& Pylkkänen, Anu \& Sandlund, Tom \& Toivanen, Reetta (eds.), New Challenges for the Welfare Society. Publications of Karelian Institute N:o 142. Joensuu: Yliopistopaino.

DOUGLAS, MARY 1987: How Institutions Think. London: Routledge.

DOUGLAS, MARY 2000: Chistota i opasnost'. Analizpredstavlenij ob oskvernenii i tabu. Moskva: Kanon-Press-C. [1966]

DOVLATOV, SERGEI 1995: Kompromiss - Sobranie sochinenij v 3-h tomah, tom 1. Sankt-Peterburg: Limbus-Press.

EKLUND, HILKKA 1995: Kansallinen teatteri improvisoi ohjelmistopolitiikkansa. - Carelia 67(8): 101-106.

FLINK, TOIVO 1997: Yhteenkuuluvuus ei tunne rajoja. - Carelia 65(8): 147-150. FINGERROOS, OUTI 2004: Haudatut muistot. Rituaalisen kuoleman merkitykset Kannaksen muistitiedossa. Suomalaisen Kirjallisuuden Seuran Toimituksia 985. Helsinki: Suomalaisen Kirjallisuuden Seura.

VAN GENNEP, ARNOLD 1977: The Rites of Passage. London: Routledge and Kegan Paul. [1909]

HAKAMIES, PEKKA 1998: Perinne, etninen identiteetti ja yhteiskunnan murros. - Hakamies, Pekka (toim.), Ison karbun jälkeläiset. Suomalaisen Kirjallisuuden Seuran Toimituksia 697. Helsinki: Suomalaisen Kirjallisuuden Seura.

HALL, STUART 1999: Identiteetti. Tampere: Vastapaino.

HAUTANIEMI, PETRI 2004: Pojat! Somalipoikien kiistanalainen nuoruus Suomessa. Nuorisotutkimusseuran julkaisuja 41. Helsinki: Nuorisotutkimusverkosto.

HEIKKINEN, KAIJA 1985: Folklorismin monet muodot. Esimerkki Neuvostoliiton juhlapeinteestä. - Tiede \& Edistys 2/1985: 119-131.

- 2003: Nationalistinen karelianismi paluumuuttajien kiusana. - Simola, Raisa \& Heikkinen, Kaija (toim.), Monenkirjava rasismi. Joensuu: Joensuu University Press. HUNTINGTON, RICHARD \& METCALF, PETER 1979: Celebrations of Death. The Anthropology of Mortuary Rituals. Cambridge: Cambridge University Press.

HUTTUNEN, LAURA 2002: Kotona, maanpaossa, matkalla. Kodin merkitykset maahanmunttajien omaelämäkerroissa. Suomalaisen Kirjallisuuden Seuran Toimituksia 861. Helsinki: Suomalaisen Kirjallisuuden Seura. 
RItUAALI, IDENTITEETTI JA YLIRAJAISUUS

INKERINSUOMALAISTEN MAAHANMUUTTO SUOMEEN 1990-LUVULLA, 1998: Hallituksen selonteko eduskunnan ulkoasiainvaliokunnalle. Helsinki: Työministeriö.

JETSU, LAURA 2001: Kahden maailman välillä. Etnografinen tutkimus venäjänkarjalaisista hautausrituaaleista 1990-luvulla. Suomalaisen Kirjallisuuden Seuran Toimituksia 853. Helsinki: Suomalaisen Kirjallisuuden Seura.

KACHKIN, ALEKSANDR 2000, 2003 [online]: Etnicheskaja mobilizacija i process regionalizacii: formy i mehanizmy. < http://www.hse.ru/journals/wrldross/vol00_4/ kachkin.htm > [4.8.2004.]

KALEDIN, SERGEI 1987: Smirennoe kladbishtshe. - Koridor. Moskva: Sovetskij pisatel'.

KANSALAISUUSLAKI 2003 [online]. < http://www.finlex.fi/linkit/sd/20030359 $>$ [3.3.2005.]

KOLOMAINEN, ROBERT 1994: Rehellisyys maan perii. Myös Inkerinmaan? - Carelia 66(10): 34-38.

- 1995: Paikka maan päällä ja paikka historiassa. - Carelia 67(10): 3-4.

KONKKA, UNELMA 1980: Semeinye obrjady. - Konkka, Unelma \& Konkka, A. (red.), Dubornaja kul'tura segozerskih karel konca XIX - nachala XX v. Leningrad: Nauka. KOZHANOV, A.A. \& JALOVITSYNA, S.E. 1998: Etnosotsiologicheskoje obsledovanije finskogo naselenija Karelii: osnovnye zadachi i pervye rezul'taty. - Kiuru, E.S. (toim.), Finny v Rossï: istorija, kul'tura, sud'by. Petrozavodsk: Izdatel'stvo Petrozavodskogo universiteta.

KREMLJOVA, I.A. 1999: Pohoronno-pominal'nye obychai i obrjady. Aleksandrov, V.A. \& Vlasova, I.V. \& Polishtshuk, N.S. (red.), Russkie. Moskva: Nauka. KÄÄRIÄINEN, KIMMO 2004: Ateismin jälkeen. Uskonnollisuus Venäjällä. Kirkon tutkimuskeskuksen julkaisuja 86. Tampere: Kirkon tutkimuskeskus.

LAVONEN, NINA 1995: Havaintoja hautajaisrituaalista Aunuksen Karjalassa.

- Hakamies, Pekka (toim.), Näkökulmia karjalaiseen perinteeseen. Suomi 182. Helsinki: Suomalaisen Kirjallisuuden Seura.

LEPOLA, OUTI 2000: Ulkomaalaisesta suomenmaalaiseksi. Monikulttuurisuus, kansalaisuus ja suomalaisuus 1990-luvun maahanmunttopoliittisessa keskustelussa. Suomalaisen Kirjallisuuden Seuran Toimituksia 787. Helsinki: Suomalaisen Kirjallisuuden Seura.

MAKASHINA, T. S. 1995: Russkaja svad'ba: sozdanie sovremennogo obrjada i tradicija. - Listova, T. A. \& Gromyko, M.M. \& Polishtshuk, N.S. \& Shmeljova, M.N. \& Slepcova, I.S. (red.), Russkie narodnye tradicii i sovremennost'. Moskva: Nauka. MALINOWSKI, BRONISLAW 1960: Magia, tiede ja uskonto sekä muita esseitä. PorVOO: WSOY.

PAKKANEN, SANTERI 1992: Martin Luther ja muovipussi. Neuvostoliiton suomalaiset ja Suomi. - Carelia 64(2): 92-95.

PIETIKÄINEN, SARI \& LAIHIALA-KANKAINEN, SIRKKA 2004: Venäjänkieliset marginaalista mediaan. - Idäntutkimus 11(4): 9-20. 


\section{Olga DaVydova}

RJABOV, OLEG 2001: «Matushka-Rus’». Opyt gendernogo analiza poiskov nacional'noi identichnosti Rossii v otechestvennoi i zapadnoi istoriosofii. Moskva: Nauchno-izdatel'skij centr "Ladomir".

SHEVCHENKO, V.F. 2003: Pohoronnye i pominal'nye ritualy. - Neljudov S. Ju. (red.), Sovremennyi gorodskoi fol'klor. Moskva: Rossijskij gosudarstvennyi gumanitarnyi universitet.

SURVO, ARNO 2001: Magian kieli. Neuvosto-Inkeri symbolisena periferiana. Suomalaisen Kirjallisuuden Seuran Toimituksia 820. Helsinki: Suomalaisen Kirjallisuuden Seura.

SURHASKO, JU. JU. 1985: Semeinye obrjady i verovanija karel: konec XIX - nachalo XX v. Leningrad: Nauka.

TAKALA, I.R. 1998: Finny-immigranty. - Kiuru, E.S. (toim.), Finny v Rossii: istorija, kul'tura, sud'by. Petrozavodsk: Izdatel'stvo Petrozavodskogo universiteta.

TURNER, VICTOR 1977: The Ritual Process. Structure and Anti-Structure. Ithaca, N.Y.: Cornell University Press. [1969]

ULKOMAALAISLAKI 2003 [online]: < http:// finlex1.edita.fi/dynaweb/stp/stp/ 2003sd/@ebt-link?showtoc=false;target=IDMATCH(id,20030218.sd > [3.3.2005.] VOUTILAINEN, PAAVO 1995: Toimipiste toimi tehokkaasti, mutta paluumuuttajajono on kasvanut. - Carelia 67(3): 112-119.

\section{Olga Davydova (FL) on folkloristi ja toimii tutkijana Karjalan tutkimuslai- toksella Joensuussa.}

